\title{
Electrochemical Impedance Study of Carbon-Supported Pt/Mo-Oxide for CO-Tolerant Anode Catalyst
}

\author{
Tsutomu IoroI, * Shin-ichi Yamazaki, Zyun Siroma, Naoko Fujiwara, \\ and Kazuaki YASUDA
}

\begin{abstract}
National Institute of Advanced Industrial Science and Technology (AIST), Research Institute for Ubiquitous Energy Devices (1-8-31 Midoriga-oka, Ikeda, Osaka 563-8577, Japan)
\end{abstract}

Received July 31, 2006 ; Accepted September 1, 2006

\begin{abstract}
The CO-tolerance of a carbon-supported $\mathrm{Pt} / \mathrm{Mo}$-oxide $(\mathrm{Pt} / \mathrm{MoOx} / \mathrm{C})$ anode in proton-exchange membrane fuel cells was examined by electrochemical impedance spectroscopy. A pseudo-inductive loop was clearly observed only for a $\mathrm{Pt} / \mathrm{MoOx} / \mathrm{C}$ anode at low anodic polarizations, which indicates the onset of the electro-oxidation of adsorbed $\mathrm{CO}\left(\mathrm{CO}_{\mathrm{ad}}\right)$ on the $\mathrm{Pt} / \mathrm{MoOx} / \mathrm{C}$ catalyst. The $\mathrm{CO}$-tolerance of $\mathrm{Pt} / \mathrm{MoOx} / \mathrm{C}$ at low anodic polarizations is mainly ascribed to the combination of the electro-oxidation of $\mathrm{CO}_{\mathrm{ad}}$ and the removal of $\mathrm{CO}$ by the water-gas shift reaction depending on the operating conditions.
\end{abstract}

Key Words : PEMFC, Electrocatalyst, Molybdenum Oxide, Carbon Monoxide

\section{Introduction}

The poisoning of an anode catalyst by carbon monoxide (CO) is a main cause of anodic voltage loss in reformate-feed PEMFCs. ${ }^{1)}$ To overcome this loss due to COpoisoning, many Pt-based catalysts including alloys and oxides have been proposed. ${ }^{2)}$ Although carbon-supported $\mathrm{PtRu}$ alloys $(\mathrm{PtRu} / \mathrm{C})$ are state-of-the-art anode catalysts, the CO-tolerance of PtRu is still unsatisfactory for higher $\mathrm{CO}$ concentrations. In addition, the limited availability of $\mathrm{Ru}$ may become a significant problem before the mass production of PEMFC systems can be realized.

As alternatives to a PtRu catalyst, PtMo alloy catalysts have attracted considerable attention due to their high catalytic activity in the anodic oxidation of $\mathrm{H}_{2}$ under $\mathrm{CO} / \mathrm{H}_{2}$ feed. ${ }^{3)}$ Previously, we reported the improved COtolerance of a carbon-supported nano-sized Pt/Mo-oxide $(\mathrm{Pt} / \mathrm{MoOx} / \mathrm{C})$ heterogeneous catalyst. ${ }^{4-6)}$ Polarization measurements combined with gas analyses at the anode outlet revealed that $\mathrm{Pt} / \mathrm{MoOx} / \mathrm{C}$ shows better $\mathrm{CO}$-tolerance than $\mathrm{PtRu} / \mathrm{C}$ for $\mathrm{CO} / \mathrm{H}_{2}$ mixtures and they have different mechanisms for the toleration of $\mathrm{CO}$ at low potentials ( $<100 \mathrm{mV}$ vs RHE); the CO-tolerance of $\mathrm{Pt} / \mathrm{MoOx} / \mathrm{C}$ is mainly due to the higher catalytic activity for the watergas shift (WGS) reaction (eq.1) and the electro-oxidation of $\mathrm{CO}$ (eq.2).

$$
\begin{gathered}
\mathrm{CO}+\mathrm{H}_{2} \mathrm{O} \leftrightarrows \mathrm{CO}_{2}+\mathrm{H}_{2} \\
\mathrm{CO}+\mathrm{H}_{2} \mathrm{O} \leftrightarrows \mathrm{CO}_{2}+2 \mathrm{H}^{+}+2 \mathrm{e}^{-}
\end{gathered}
$$

Electrochemical impedance spectroscopy (EIS) is a useful tool for analyzing electrochemical processes at a steady state by using an alternating signal of small magnitude to perturb the cell. EIS has the advantage of separating different rate processes in the frequency domain, and this technique has been demonstrated to provide valuable information for processes that involve the adsorption of $\mathrm{CO}$ on the catalyst surface in a PEMFC. ${ }^{7.8)}$ In this paper, the anodic reaction on $\mathrm{at} / \mathrm{MoOx} / \mathrm{C}$ anode under $\mathrm{CO} / \mathrm{H}_{2}$ feed in PEMFC was examined by EIS measurements, and the intrinsic CO-tolerance properties of $\mathrm{Pt} / \mathrm{MoOx} / \mathrm{C}$ at low anodic polarizations are discussed.

\section{Experimental}

The $\mathrm{Pt} / \mathrm{MoOx} / \mathrm{C}$ electrocatalyst was prepared inhouse by following the procedure described in previous reports. ${ }^{4-6)}$ Briefly, $\mathrm{MoCl}_{5}$ (Aldrich, reagent grade) was used as a Mo source for MoOx deposition. The carbon support material (Vulcan XC-72R, Cabot) was dispersed in $\mathrm{MoCl}_{5}$ solution to give $9 \mathrm{wt} \%$ Mo content (nominal), and the $\mathrm{pH}$ of the solution was then adjusted to 7-8 by the addition of $2.5 \%\left(\mathrm{CH}_{3}\right)_{4} \mathrm{NOH}$ (Wako, reagent grade) solution to precipitate hydrous $\mathrm{MoOx}$ on the support. After filtering, drying and washing, the Mo-deposited carbon was heated at $400{ }^{\circ} \mathrm{C}$ for $6 \mathrm{~h}$ under flowing $\mathrm{N}_{2}$ to obtain stable $\mathrm{MoOx} / \mathrm{C}$ catalyst. For Pt deposition on the $\mathrm{MoOx} / \mathrm{C}$ catalyst, $\mathrm{Pt}\left(\mathrm{NO}_{2}\right)_{2}\left(\mathrm{NH}_{3}\right)_{2}$ solution was used. The Pt-impregnated $\mathrm{MoOx} / \mathrm{C}$ was reduced at $250{ }^{\circ} \mathrm{C}$ for $5 \mathrm{~h}$ under flowing $\mathrm{H}_{2}$ atmosphere to give $\mathrm{Pt} / \mathrm{MoOx} / \mathrm{C}$ catalyst. The catalyst metal (Pt) loading density was $30 \mathrm{wt} . \%$ for $\mathrm{Pt} / \mathrm{MoOx} / \mathrm{C}$ throughout this study. To compare the CO-tolerance properties of the prepared $\mathrm{Pt} / \mathrm{MoOx} / \mathrm{C}$ catalysts with the state-of-the-art $\mathrm{PtRu} / \mathrm{C}$ catalyst, $45 \mathrm{wt} . \%$ PtRu(1:1)/C supplied from Johnson Matthey Inc. (HiSPEC7000 Fuel Cell Catalyst) was used as a standard anode catalyst. As a cathode catalyst, we used $40 \mathrm{wt} . \%$ $\mathrm{Pt} / \mathrm{C}$ (Johnson Matthey Inc., HiSPEC4000 Fuel Cell Catalyst).

The CO-tolerance properties of the catalysts were examined by testing the performance of a small-scale single cell (active area of 2 or $10 \mathrm{~cm}^{2}$ ). Membrane electrode assemblies (MEAs) were prepared by the "decal method". Catalyst "ink" was prepared by mixing catalyst 
material, ionomer solution (5 wt.\% Nafion, Aldrich) and 2propanol (Wako, reagent grade). Ionomer/carbon weight ratios were $c a$. 0.5/1. The catalyst slurry-coated PTFE films for the anode and cathode were placed on both sides of a pre-treated Nafion112 membrane and then hotpressed at $140{ }^{\circ} \mathrm{C}$ for 2 min to form MEA. Specific catalyst loadings for anode and cathode are given in the figure captions.

Evaluations of cell performance and CO-tolerance were conducted using a custom in-house test bench. As anode reactants, pure hydrogen and $\mathrm{CO}(80$ or $100 \mathrm{ppm}) / \mathrm{H}_{2}$ were used to examine the poisoning effect of $\mathrm{CO}$ in the fuel stream. As a cathode reactant, pure oxygen was supplied in large excess $\left(100 \mathrm{~mL} \mathrm{~min}^{-1}\right)$ to avoid any instability associated with mass transport in the cathode. During fuel cell testing, the cell was maintained at $80^{\circ} \mathrm{C}$ and at atmospheric pressure. The reactants were humidified by bubbling the gases through water in stainless steel bottles thermostated at $80{ }^{\circ} \mathrm{C}$. The current-voltage relationships (polarization curves) of the cells were obtained galvanostatically using a PC-controlled electronic load system (Scribner Associates Inc., Model890CL). All of the electrochemical impedance spectra were recorded using a Solartron SI1260 frequency response analyser/SI1287 potentio-galvanostat system. The impedance spectra were measured in the frequency range of 5 $\mathrm{kHz}$ to $10 \mathrm{mHz}$ under the constant current mode, and the applied amplitude was set to $10 \%$ of DC current. To obtain impedance spectra of the anode and cathode separately, a small auxiliary electrode was placed beside the anode to serve as a reference electrode.

\section{Results and Discussion}

Figure 1 shows typical steady-state polarization curves of single cells using $\mathrm{Pt} / \mathrm{MoOx} / \mathrm{C}$ catalyst as an anode on pure $\mathrm{H}_{2}$ and $\mathrm{CO}(80 \mathrm{ppm}) / \mathrm{H}_{2}$ with a fuel utilization factor $\left(U_{\mathrm{f}}\right.$ : a inverse of fuel stoichiometry) of 0.7 along with that using $\mathrm{PtRu} / \mathrm{C}$ catalyst. While the cell performances are

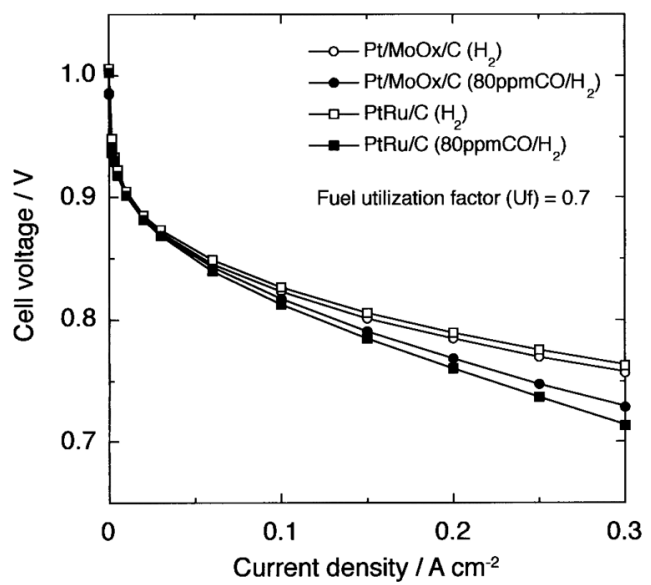

Fig. 1 Polarization curves of a single cell with $\mathrm{Pt} / \mathrm{MoOx} / \mathrm{C}$ and $\mathrm{PtRu} / \mathrm{C}$ anodes under pure $\mathrm{H}_{2}$ and $\mathrm{CO}(80 \mathrm{ppm}) / \mathrm{H}_{2}$. Cell operating conditions; cell temperature: $80{ }^{\circ} \mathrm{C}$, reactant gases: humidified at $80^{\circ} \mathrm{C}$ without back-pressure. Catalyst loadings; anode: $c a .0 .3 \mathrm{mg}-\mathrm{Pt} \mathrm{cm}^{-2}\left(0.4 \mathrm{mg}\right.$-PtRu $\left.\mathrm{cm}^{-2}\right)$, cathode: $0.5 \mathrm{mg}$ $\mathrm{Pt} \mathrm{cm}^{-2}$. very similar under feeding with pure $\mathrm{H}_{2}$, the effects of 80 ppm $\mathrm{CO}$ on cell voltage vary depending on the anode catalyst; $\mathrm{Pt} / \mathrm{MoOx} / \mathrm{C}$ showed a smaller voltage loss on $\mathrm{CO}(80 \mathrm{ppm}) / \mathrm{H}_{2}$ than $\mathrm{PtRu} / \mathrm{C}$, as shown in a previous paper. ${ }^{6}$

The impedance spectra of $\mathrm{Pt} / \mathrm{MoOx} / \mathrm{C}$ and $\mathrm{PtRu} / \mathrm{C}$ under the same operating condition $\left(0.3 \mathrm{~A} \mathrm{~cm}^{-2}, 80\right.$ $\left.\mathrm{ppmCO} / \mathrm{H}_{2}, U_{\mathrm{f}}=0.05\right)$ are compared in Fig. 2. There is an apparent difference in the impedance plots in the low frequency range. The impedance plot of $\mathrm{PtRu} / \mathrm{C}$ anode for $\mathrm{CO} / \mathrm{H}_{2}$ oxidation is a usual capacitive arc, whereas that of $\mathrm{Pt} / \mathrm{MoOx} / \mathrm{C}$ anode consists of a usual capacitive semi-circle followed by an additional pseudo-inductive semi-circle in the lower frequency range. Similar pseudoinductive behavior has been reported for Faradaic processes involving adsorbed intermediates such as anodic corrosion reactions of metals. ${ }^{9)}$ Conway et al. ${ }^{9}$ showed by the electrode kinetic model approach that a negative slope in plots of adsorbate coverage vs. electrode potential is associated with the pseudo-inductive behavior. For a PEMFC system, such pseudo-inductive impedance plots have also been reported for $\left.\mathrm{CO} / \mathrm{H}_{2}{ }^{7,8}\right)$ and methanol ${ }^{10)}$ oxidation reactions on $\mathrm{Pt} / \mathrm{C}$ or $\mathrm{PtRu} / \mathrm{C}$ anodes at relatively high anodic polarizations $(>0.3-0.55 \mathrm{~V}$, depending on the experimental conditions). Ciureanu et $a l^{7}{ }^{7}$ reported that the appearance of the characteristic inductive loop for the anode fed with $\mathrm{CO} / \mathrm{H}_{2}$ is an indication of the onset of electro-oxidation of the adsorbed $\mathrm{CO}$ on $\mathrm{Pt} / \mathrm{C}$ or $\mathrm{PtRu} / \mathrm{C}$. Considering the similarity of the Ptbased catalyst between $\mathrm{Pt} / \mathrm{C}$ and $\mathrm{Pt} / \mathrm{MoOx} / \mathrm{C}$, it is reasonable to expect that the origin of the pseudo-inductive behavior of $\mathrm{Pt} / \mathrm{MoOx} / \mathrm{C}$ should also be the electro-oxidation of $\mathrm{CO}_{\text {add }}$.

Figure 3 shows the Tafel plots of anodic polarizations $\left(\eta_{\mathrm{a}}\right)$ of $\mathrm{Pt} / \mathrm{MoOx} / \mathrm{C}$ and $\mathrm{PtRu} / \mathrm{C}$ anodes. At the cell operating condition of Fig. 2 (current density of $0.3 \mathrm{~A} \mathrm{~cm}^{-2}, U_{\mathrm{f}}$ $=0.05$ ), both $\mathrm{Pt} / \mathrm{MoOx} / \mathrm{C}$ and $\mathrm{PtRu} / \mathrm{C}$ anodes show similar low anodic polarizations; $\eta_{\mathrm{a}}$ are $c a .60$ and $40 \mathrm{mV}$ vs RHE at $0.3 \mathrm{~A} \mathrm{~cm}^{-2}$, respectively. These anodic polarizations are much lower than the reported onset potential

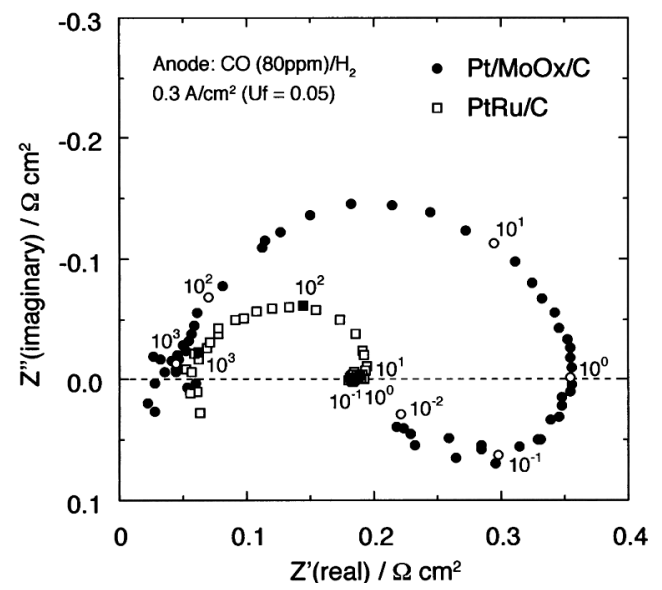

Fig. 2 Impedance plots of $\mathrm{Pt} / \mathrm{MoOx} / \mathrm{C}$ and $\mathrm{PtRu} / \mathrm{C}$ anodes at $0.3 \mathrm{~A} \mathrm{~cm}^{-2}, U_{\mathrm{f}}=0.05$ under $\mathrm{CO}(80 \mathrm{ppm}) / \mathrm{H}_{2}$ feed. The numbers in the diagram indicate the frequency $(\mathrm{Hz})$. Cell operating conditions; see Fig. 1. 
of pseudo-inductive loops for $\mathrm{Pt} / \mathrm{C}$ or $\mathrm{PtRu} / \mathrm{C}$ anodes (E $\left.>0.3-0.55 \mathrm{~V}),{ }^{7}\right)$ as described above.

Previously, we reported the results of comparative evaluations of the CO-tolerance of $\mathrm{Pt} / \mathrm{MoOx} / \mathrm{C}$ and $\mathrm{PtRu} / \mathrm{C}$ anodes by polarization measurement $\left(0.3 \mathrm{~A} \mathrm{~cm}^{-2}\right.$, $80 \mathrm{ppm} \mathrm{CO} / \mathrm{H}_{2}$ ) combined with $\mathrm{CO}$ concentration analyses at the anode outlet. $\left.{ }^{6}\right)$ For the $\mathrm{Pt} / \mathrm{MoOx} / \mathrm{C}$ anode, a decrease in the $\mathrm{CO}$ concentration was observed regardless of the anode potential, which indicates that $\mathrm{Pt} / \mathrm{MoOx} / \mathrm{C}$ catalyst facilitates $\mathrm{CO}$ oxidation by WGS reaction (eq. 1), and partly by electro-oxidation reaction (eq. 2). In contrast, a decrease in the CO concentration was not observed for $\mathrm{PtRu} / \mathrm{C}$ anode, which indicates that $\mathrm{PtRu} / \mathrm{C}$ catalyst does not proceed both WGS and electrooxidation reactions at low anodic polarizations including open-circuit conditions. Therefore, appearance of the inductive loop for the impedance plot of $\mathrm{Pt} / \mathrm{MoOx} / \mathrm{C}$ in Fig. 2 clearly shows that the electro-oxidation of $\mathrm{CO}_{\mathrm{ad}}$ proceeds even at such a low anodic polarization only for $\mathrm{Pt} / \mathrm{MoOx} / \mathrm{C}$ anode.

The CO-tolerance of $\mathrm{Pt} / \mathrm{MoOx} / \mathrm{C}$ catalyst depends on the operating condition such as current density, and $U_{\mathrm{f}}$. Figure 4 shows the impedance spectra of the $\mathrm{Pt} / \mathrm{MoOx} / \mathrm{C}$ anode at different current loading conditions. A pseudo-inductive loop was observed for plots at a current density $\geq 0.2 \mathrm{~A} \mathrm{~cm}^{-2}$, whereas an inductive loop disappeared at $0.1 \mathrm{~A} \mathrm{~cm}^{-2}$; this fact indicates that anodic polarization at $0.1 \mathrm{~A} \mathrm{~cm}^{-2}\left(\eta_{\mathrm{a}} \approx 20 \mathrm{mV}\right.$ from Fig. 3) was not enough for the electro-oxidation of $\mathrm{CO}_{\mathrm{ad}}$ on $\mathrm{Pt} / \mathrm{MoOx} / \mathrm{C}$. Thus, the onset potential for $\mathrm{CO}_{\mathrm{ad}}$ oxidation on $\mathrm{Pt} / \mathrm{MoOx} / \mathrm{C}$ should lie between 20 and $40 \mathrm{mV}$. This result agrees with that reported by $\mathrm{Crabb}$ et al. ${ }^{11)}$ with PtMoOx/C catalyst in $1 \mathrm{M} \mathrm{H}_{2} \mathrm{SO}_{4}$ at $353 \mathrm{~K}$, which showed $\mathrm{CO}$ oxidation activity at potentials above $25 \mathrm{mV}$ vs RHE. The electro-oxidation of $\mathrm{CO}$ is thermodynamically possible reaction at $\mathrm{H}_{2}$-fed anode because the standard electrode potential $E^{0}\left(25^{\circ} \mathrm{C}\right)$ of the electro-oxidation of $\mathrm{CO}$ (eq. 2) is $-0.106 \mathrm{~V} .^{12)}$ Thus, it appears that the activation of the electro-oxidation reaction of $\mathrm{CO}$ on the $\mathrm{Pt} / \mathrm{MoOx} / \mathrm{C}$ anode needs anodic polarization of $c a$. 0.13-

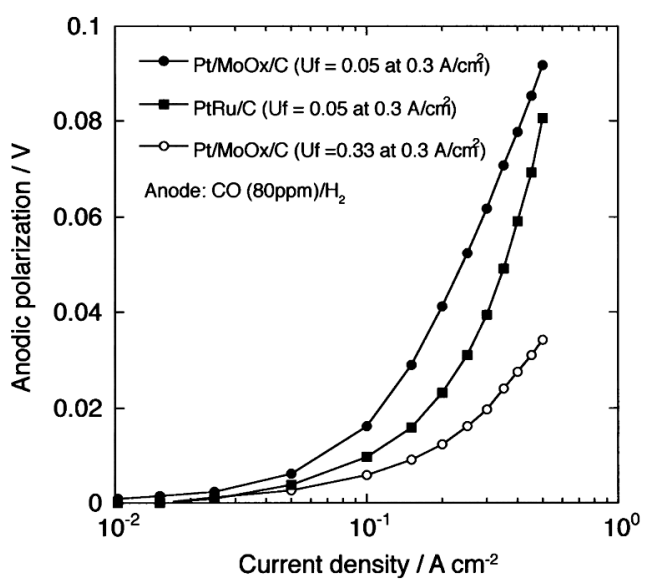

Fig. 3 Anodic polarization vs. current density plots of $\mathrm{Pt} / \mathrm{MoOx} / \mathrm{C}$ and $\mathrm{PtRu} / \mathrm{C}$ anodes at constant fuel flow rate (equivalent to $U_{\mathrm{f}}=0.05,0.33$ at $\left.0.3 \mathrm{~A} \mathrm{~cm}^{-2}\right)$ under $\mathrm{CO}(80$ $\mathrm{ppm}) / \mathrm{H}_{2}$ feed. Cell operating conditions; see Fig. 1.
$0.15 \mathrm{~V}$. Therefore, at the potentials examined here (0-100 $\mathrm{mV}$ vs $\mathrm{RHE}$ ), the $\mathrm{Pt} / \mathrm{MoOx} / \mathrm{C}$ anode shows two regions divided by the onset potential of the electro-oxidation of $\mathrm{CO}_{\mathrm{ad}}$; the catalytic WGS reaction dominates below the onset potential, whereas both WGS and the $\mathrm{CO}_{\mathrm{ad}}$ electrooxidation reaction take place beyond this potential.

The impedance patterns of the $\mathrm{Pt} / \mathrm{MoOx} / \mathrm{C}$ anode at different $U_{\mathrm{f}}$ conditions are compared in Fig. 5. The anode was fed $\mathrm{CO}(80 \mathrm{ppm}) / \mathrm{H}_{2}$ and the loading current was set at $0.5 \mathrm{~A} \mathrm{~cm}^{-2}$. The electrode impedance decreased dramatically with an increase in $U_{\mathrm{f}}$ from 0.08 to 0.5 , which suggests that $\mathrm{CO}$-poisoning of the $\mathrm{Pt} / \mathrm{MoOx} / \mathrm{C}$ anode is alleviated under high $U_{\mathrm{f}}$ conditions. In fact, the anodic polarization of $\mathrm{Pt} / \mathrm{MoOx} / \mathrm{C}$ anode at high $U_{\mathrm{f}}$ condition is much smaller than that of low $U_{\mathrm{f}}$ as shown in Fig. 3. In addition, the pseudo-inductive loop for high $U_{\mathrm{f}}$ is much smaller than that for low $U_{\text {f. }}$ Since WGS (eq. 1) is thermodynamically possible reaction at $80^{\circ} \mathrm{C}\left(\Delta G_{\mathrm{f}}^{\text {shift }}=-26.4\right.$ $\mathrm{kJ} / \mathrm{mol})^{13)}$ and the equilibrium of the WGS reaction lies much more to the right due to the small space velocity of fuel under high $U_{\mathrm{f}}$ conditions, the $\mathrm{CO}$ concentration

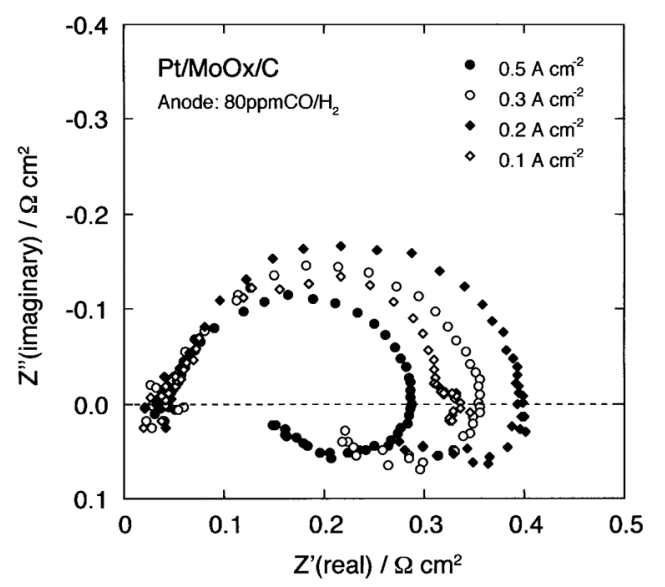

Fig. 4 Impedance plots of $\mathrm{Pt} / \mathrm{MoOx} / \mathrm{C}$ anode at different current densities $\left(0.1,0.2,0.3\right.$ and $\left.0.5 \mathrm{~A} \mathrm{~cm}^{-2}\right)$ under $\mathrm{CO}(80$ $\mathrm{ppm}) / \mathrm{H}_{2}$ feed. Cell operating conditions; see Fig. 1 .

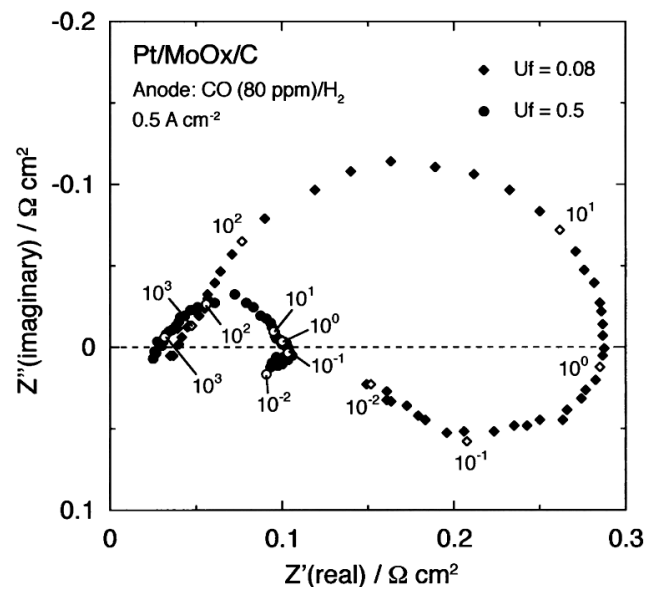

Fig. 5 Impedance plots of $\mathrm{Pt} / \mathrm{MoOx} / \mathrm{C}$ anode at different $U_{\mathrm{f}}$ conditions (0.08 and 0.5$)$ under $0.5 \mathrm{~A} \mathrm{~cm}^{-2}$ loading and $\mathrm{CO}(80 \mathrm{ppm}) / \mathrm{H}_{2}$ feed. The numbers in the diagram indicate the frequency $(\mathrm{Hz})$. Cell operating conditions; see Fig. 1. 
decreases significantly $\left(\approx 20 \mathrm{ppm}\right.$ at the anode outlet). ${ }^{6}$ This leads to the low anodic polarization and small pseudo-inductive loop at high $U_{\mathrm{f}}$ conditions.

\section{Conclusions}

The CO-tolerance of a $\mathrm{Pt} / \mathrm{MoOx} / \mathrm{C}$ anode was examined by electrochemical impedance analyses. Even at anodic polarizations as low as $40 \mathrm{mV}$ vs. RHE, a characteristic pseudo-inductive loop was observed in the impedance plots for $\mathrm{Pt} / \mathrm{MoOx} / \mathrm{C}$, which indicates that the electro-oxidation of $\mathrm{CO}_{\mathrm{ad}}$ on the $\mathrm{Pt} / \mathrm{MoOx} / \mathrm{C}$ catalyst proceeds at such low potentials. This result shows that the electro-oxidation reaction of $\mathrm{CO}_{\mathrm{ad}}$ plays an important role in the $\mathrm{CO}$-tolerance of $\mathrm{Pt} / \mathrm{MoOx} / \mathrm{C}$ anode under practical operating conditions.

\section{Acknowledgments}

This work was supported by the New Energy and Industrial Technology Development Organization (NEDO), Research and Development of Polymer Electrolyte Fuel Cell Project.

\section{References}

1) S. Gottesfeld and J. Pafford, J. Electrochem. Soc., 135, 2651 (1988).

2) S. J. Cooper, A. G. Gunner, G. Hoogers, and D.
Thompsett, Proceedings of the Second International Symposium on New Materials for Fuel Cells and Modern Battery Systems, Montreal, p. 286, (1997).

3) B. N. Grgur, N. M. Markovic, and P. N. Ross, J. Phys. Chem. B, 102, 2494 (1998).

4) T. Ioroi, N. Fujiwara, Z. Siroma, K. Yasuda, and Y. Miyazaki, Electrochem. Commun., 4, 442 (2002).

5) T. Ioroi, K. Yasuda, Z. Siroma, N. Fujiwara, and Y. Miyazaki, J. Electrochem. Soc., 150, A1225 (2003).

6) T. Ioroi, T. Akita, S. Yamazaki, Z. Siroma, N. Fujiwara, and K. Yasuda, Electrochim. Acta., 52, 491 (2006).

7) M. Ciureanu and H. Wang, J. Electrochem. Soc., 146, 4031 (1999).

8) X. Wang, I. M. Hsing, Y. J. Leng, and P. L. Yue, Electrochim. Acta., 46, 4397 (2001).

9) L. Bai and B. E. Conway, J. Electrochem. Soc., 138, 2897 (1991).

10) I. M. Hsing, X. Wang, and Y. J. Leng, J. Electrochem. Soc., 149, A615 (2002).

11) E. M. Crabb, M. K. Ravikumar, Y. Qian, A. E. Russell, S. Maniguet, J. Yao, D. Thompsett, M. Hurford, and S. C. Ball, Electrochem. Solid-State Lett., 5, A5 (2002).

12) Z. Galus, Standard Potentials in Aqueous Solution (Eds. A. J. Bard, R. Parsons, and J. Jordan), Marcel Dekker, New York, NY, p.195 (1985).

13) I. Barin, Thermodynamic Data of Pure Substances, VCH, Weinheim (1989). 